\title{
Casino Gaming and Local Employment Trends
}

\author{
Thomas A. Garrett
}

\section{THE U.S. CASINO INDUSTRY}

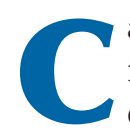

asino gaming has become a major industry in the United States over the past two decades. Prior to the late 1980s, casino gaming was legal only in Nevada and Atlantic City, New Jersey. Today, casino gaming is available in 29 states. As a consequence, annual gaming revenue has grown from $\$ 9$ billion in 1991 to over $\$ 40$ billion in 2001. ${ }^{1}$ Americans spend more money in casinos than individually on golf, on-screen movies, CDs and sound equipment, and cable TV. ${ }^{2}$

The casino industry consists of two major parties-Indian tribes and publicly traded private corporations such as Harrah's Entertainment and Trump Hotels and Casino Resorts. The Indian Gaming Regulatory Act (Public Law 100-497, passed in 1988) allows Indian tribes to own and operate casinos on their reservations. Tribal gaming is available in 25 states and generates nearly $\$ 13$ billion in annual revenue. Corporate casino gaming is available in 10 states and generated over $\$ 27$ billion in revenue in $2001 .^{3}$ Table 1 provides a listing of these states. ${ }^{4}$

\footnotetext{
1 Casino revenues in this report represent revenue to the casinos after subtracting player winnings. In comparison, 38 state lotteries generated nearly $\$ 38$ billion in 2001; pari-mutuel horse and greyhound racing generated over $\$ 3.25$ billion (legal in 43 states) and $\$ 550$ million (legal in 15 states), respectively.

2 From the American Gaming Association (www.americangaming.org)

3 West Virginia, Delaware, Rhode Island, Louisiana, Iowa, and New Mexico offer video lottery terminals (VLTs) and slot machines as part of their state lottery. These outlets (often called racinos) are usually located at pari-mutuel racetracks and are not considered corporate casinos because they are run by the state. The revenue from these outlets (roughly $\$ 500$ million annually) is considered a portion of total lottery revenue.

4 Most data presented in this report are from the following sources: Bear Stearns 2002-2003 North American Gaming Almanac (Ader, 2003); The National Gambling Impact Study Commission, Final Report (1999), www.casino-gambling-reports.com/GamblingStudy/; the American Gaming Association, www.americangaming.org; and each state's gaming commission.
}

While tribal gaming is available in more states, corporate casino gaming has traditionally been perceived as a more appropriate tool for fostering general economic development through increased employment and tax revenue. ${ }^{5}$ The primary reason for this perception is that states have no power to tax Indian casino revenue because Indian reservations are sovereign entities, distinct from the state. ${ }^{6}$ While states and Indian tribes do cooperate on regulation and security issues (dictated by state-tribal gaming compacts), the relationship between a tribe and a state is very similar to the relationship between two states-one state generally cannot legally dictate what another state can do. Corporate casinos, however, are private industries that are taxed and regulated by the state. These casinos generate much more revenue and hire more labor from the general labor market than Indian casinos.

The impact of corporate casino gaming on local employment is a major issue in the debate over legalized casino gaming. As a result, the issue has received careful study. ${ }^{7}$ This paper explores how corporate casinos affect employment in six Midwestern counties using various employment data and forecasting models. Changes in both household and payroll employment are examined to separate the effects on the residents and businesses in counties with casinos. Payroll employment changes may allude to possible interindustry substitution resulting from casino gaming. Also, both urban and rural "casino counties" are used in the analysis to

\footnotetext{
5 Indian tribes use their gaming revenue to promote economic development on their reservations. Economic development from corporate casino gaming, however, has the potential to affect a much greater population.

6 States have negotiated payments from tribes in return for certain services such as security and improving and maintaining highway access to their casinos.

7 Gazel, Thompson, and Rickman (1995), KPMG Management Consulting (1995), and Blois, Cunningham, and Lott (1995).
}

Thomas A. Garrett is a senior economist at the Federal Reserve Bank of St. Louis. Molly D. Castelazo provided research assistance.

Federal Reserve Bank of St. Louis Review, January/February 2004, 86(1), pp. 9-22.

(C) 2004, The Federal Reserve Bank of St. Louis. 


\section{Table 1}

State Gaming Summary 2001

\begin{tabular}{|c|c|c|c|}
\hline State & Land-based casinos & Riverboat casinos & $\begin{array}{l}\text { Native American } \\
\text { casinos }\end{array}$ \\
\hline Arizona & & & $x$ \\
\hline California & & & $x$ \\
\hline Colorado & & & $x$ \\
\hline Connecticut & & & $x$ \\
\hline Florida & & & $x$ \\
\hline Idaho & & & $x$ \\
\hline Illinois & & $x$ & \\
\hline Indiana & & $x$ & \\
\hline lowa & & $x$ & $x$ \\
\hline Kansas & & & $x$ \\
\hline Louisiana & $x$ & $x$ & $x$ \\
\hline Michigan & $x$ & & $x$ \\
\hline Minnesota & & & $x$ \\
\hline Mississippi & & $x$ & $x$ \\
\hline Missouri & & $x$ & \\
\hline Montana & & & $x$ \\
\hline Nebraska & & & $x$ \\
\hline Nevada & $x$ & & $x$ \\
\hline New Jersey & $x$ & & \\
\hline New Mexico & & & $\mathrm{x}$ \\
\hline New York & & & $x$ \\
\hline North Carolina & & & $x$ \\
\hline North Dakota & & & $x$ \\
\hline Oklahoma & & & $x$ \\
\hline Oregon & & & $x$ \\
\hline South Dakota & & & $x$ \\
\hline Texas & & & $x$ \\
\hline Washington & & & $x$ \\
\hline Wisconsin & & & $x$ \\
\hline
\end{tabular}

SOURCE: Bear Stearns 2002-2003 North American Gaming Almanac (Ader, 2003, p. 16). The above list does not include those states with casinos operating as part of a state lottery. States not listed have no corporate or tribal casinos. 


\section{Table 2}

\section{Gaming Revenue for Selected States}

\begin{tabular}{lccc} 
State & 2001 revenue $\mathbf{( \$ ~ m i l l i o n s )}$ & 2000 revenue $\mathbf{( \$ ~ m i l l i o n s )}$ & Percent change \\
\hline Colorado & $\$ 675.3$ & $\$ 631.7$ & $6.9 \%$ \\
Connecticut & $1,401.6$ & $1,308.7$ & 7.1 \\
Illinois & $1,783.8$ & $1,657.8$ & 7.6 \\
Indiana & $1,841.8$ & $1,689.7$ & 9.0 \\
lowa & 922.9 & 892.6 & 3.4 \\
Louisiana & $1,883.2$ & $1,708.9$ & 10.2 \\
Michigan & $1,007.4$ & 742.9 & 35.6 \\
Mississippi & $2,700.8$ & $2,650.4$ & 1.9 \\
Missouri & $1,137.1$ & 996.6 & 14.1 \\
Nevada & $9,466.9$ & $9,599.4$ & -1.4 \\
New Jersey & $4,303.9$ & $4,299.6$ & 0.1 \\
Total & & & 3.6
\end{tabular}

NOTE: Tribal and corporate casino revenues are considered in the above figures and represent revenues to the casinos after subtracting player winnings.

SOURCE: Bear Stearns 2002-2003 North American Gaming Almanac (Ader, 2003, p. 6).

distinguish any potential differences in employment effects and to address the typical perception that casino gaming is more often seen as a savior for rural communities rather than urban communities.

\section{The Spread of Casino Gaming}

Nevada was the first state to legalize casino gaming in 1931 and has the largest gaming market in the country. The 210 casinos in Nevada generated over $\$ 9.5$ billion in revenue during 2001 . The largest concentration of casinos is in Las Vegas, with 14 casinos downtown and 47 on the "Strip" amassing nearly $\$ 5.3$ billion in revenue and attracting 35 million visitors annually to fill over 100,000 hotel rooms. Hotels downtown and on the Strip have 75,000 electronic gaming devices (EGDs-which are slot machines, video poker games, and any other electronic game used for wagering) and 3,300 table games that take up 3.3 million square feet of casino floor space. Other major markets in Nevada include Reno (\$1 billion in revenue), Laughlin (\$500 million in revenue), and Lake Tahoe ( $\$ 330$ million in revenue).

In 1976, New Jersey became the second state to legalize casino gaming, but restricted the activity to Atlantic City. Today there are 13 casinos in Atlantic City generating nearly $\$ 4.3$ billion in annual revenue and attracting 32 million visitors, making Atlantic City the second largest casino gaming market in the United States. The Atlantic City market is generally characterized as a "day-trip" destination, whereas Las Vegas is typically considered a vacation destination. Atlantic City casinos have 12,000 hotel rooms and offer 37,000 EGDs, over 1,200 table games, and nearly 1.3 million square feet of casino floor space.

The early 1990s saw a marked increase in the number of states that legalized casino gaming. Riverboat casino gaming first began in Iowa and Illinois in 1991 and quickly spread throughout the Midwest. ${ }^{8}$ Riverboat gaming now also exists in Indiana, Mississippi, and Missouri. Louisiana and Michigan legalized land-based casino gaming within the last decade. States cite the gaming industry's potential to create economic growth in the state as the primary reason for their approval of corporate casino gaming. The greatest perceived benefits are employment growth, greater tax revenue to state and local governments, and growth in local retail sales. In addition, the increasing fiscal pressures on state budgets during the 1990-91 recession, the fear

8 In many cases, the riverboat casinos are "fixed in dock," meaning that they cannot move freely along a river. 
of lost revenue to neighboring states' casinos, and a more favorable public attitude regarding casino gaming have all increased the appeal and acceptance of casinos.

Saddled with their current state budget crises, state legislators have taken up the issue of casino gaming with a renewed interest. The National Conference of State Legislatures reported in April 2003 that collective state budget gaps will approach $\$ 70$ billion in fiscal year $2004 .{ }^{9}$ As seen in Table 2, casino revenues are sizeable, making them an attractive revenue source for state and local governments. Many states are considering the expansion of casino gaming, while others such as Pennsylvania are debating whether to introduce slot machines at pari-mutuel racetracks. Several states with casino gaming have increased casino gaming tax rates within the past year or two. Also, states with Indian gaming are considering measures to extract revenue from traditionally tax-exempt Indian casinos. However, the direct taxation of tribal gaming revenue is likely to be met with serious legal challenges involving the sovereignty of Indian tribes.

\section{CASINOS AND EMPLOYMENT}

Local officials and casino proponents often claim that casinos increase local employment simply because they create additional jobs within the local area. However, several factors should be considered when evaluating the employment effects of casino gaming. These factors are applicable to any business or industry, not just casino gaming.

The relationship between casinos and employment involves the location of the casino and the required skill level of its work force. The general premise is that casinos increase employment because a casino's operation requires labor and this labor will come from the local area, thus reducing local unemployment. The question to ask is not only whether casinos decrease unemployment, but also for whom they decrease unemployment. Most casino jobs require some skill, be it accounting, dealing cards, security, or other expertise. If a casino is planning to move to a rural area that has a relatively lessskilled work force, the casino probably will draw skilled labor from outside of the area. If this labor remains outside of the local area and workers commute to the casinos, then unemployment in the local area will remain unchanged. If some of this skilled

\footnotetext{
9 Of this total, California accounts for $\$ 26$ billion. See the National
} Conference of State Legislatures State Budget Update (April 2003). labor decides to move near the casino, then the unemployment rate in the local area will fall because the labor force has increased. ${ }^{10}$ However, unemployment for the original population has remained essentially unchanged-only the new arrivals have found employment with the casino. It is the employment of these new arrivals that has decreased the unemployment rate. Thus, the promise of increased employment for the original population, which is used as an argument for the construction of casinos, may not be realized. In a relatively urban area, there is probably enough variety in the work force to ensure that skilled labor will be provided locally. In rural areas, however, most labor may be from outside of the area, thus leaving unemployment for the original population unchanged.

While casino employment is used as an indicator of economic development, true economic development occurs only when there is increased value to society. ${ }^{11}$ The introduction of casino gaming may cause local businesses to close, which will result in layoffs. ${ }^{12}$ The net increase in employment in the local area may thus be less than the number of new casino jobs. However, casino gaming may increase total employment when casinos indirectly generate noncasino jobs in the local area as a result of increased demand for non-casino goods and services. Casino employees who were previously unemployed or who recently moved into the area now generate income, and this income will be spent on goods and services such as housing and entertainment. An increase in demand for these services will increase firms' demand for labor, thereby increasing employment.

These employment "spillovers" essentially result in a positive or negative multiplier effect. The degree of this multiplier effect has been disputed in the literature. Research by Gazel, Thompson, and Rickman (1995), KPMG Management Consulting (1995), and Blois, Cunningham, and Lott (1995) suggests that a positive multiplier effect exists. However, studies by Anders, Siegel, and Yacoub (1998), Przybylski et al. (1998), and Siegel and Anders (1999) provide evidence that there is, at least to some degree,

\footnotetext{
${ }^{10}$ Recall that the unemployment rate is the number of unemployed divided by the labor force (employed + unemployed).

11 An evaluation of the social welfare effects of casino gaming should consider the benefits of casino gaming beyond employment, as well as possible costs such as addiction and crime. See Grinols (forthcoming)

12 . tainly reaches beyond county borders. Thus, economic development in one county could come at the expense of a reduction in economic activity in a neighboring county.
} 


\section{Table 3}

\section{Statistics for Counties with Casinos}

\begin{tabular}{|c|c|c|c|c|c|c|}
\hline & $\begin{array}{c}\text { Warren } \\
\text { County, } \\
\text { MS }\end{array}$ & $\begin{array}{c}\text { Tunica } \\
\text { County, } \\
\text { MS }\end{array}$ & $\begin{array}{c}\text { Massac } \\
\text { County, } \\
\text { IL }\end{array}$ & $\begin{array}{l}\text { St. Clair } \\
\text { County, } \\
\text { IL }\end{array}$ & $\begin{array}{c}\text { Lee } \\
\text { County, } \\
\text { IA }\end{array}$ & $\begin{array}{c}\text { St. Louis } \\
\text { County, } \\
\text { MO }\end{array}$ \\
\hline Casino employment & 2,443 & 12,689 & 883 & 1,184 & 367 & 2,050 \\
\hline Number of casinos in county & 4 & 9 & 1 & 1 & 1 & 1 \\
\hline County employment & 25,030 & 5,636 & 7,665 & 108,270 & 16,708 & 540,981 \\
\hline County population & 49,343 & 9,635 & 15,081 & 256,599 & 33,313 & $1,015,417$ \\
\hline $\begin{array}{l}\text { Percent (number) of casino } \\
\text { employees from home county }\end{array}$ & $\begin{array}{l}75(1,832) \\
y\end{array}$ & $30(3,807)$ & $44(389)$ & $80(947)$ & $45(165)$ & $32(656)$ \\
\hline $\begin{array}{l}\text { County unemployment rate, } \\
\text { pre-casino }(\%)\end{array}$ & 8.8 & 10.7 & 9.5 & 9.4 & 3.7 & 3.1 \\
\hline $\begin{array}{l}\text { County unemployment rate, } \\
\text { post-casino }(\%)\end{array}$ & 4.2 & 7.1 & 4.4 & 5.9 & 3.3 & 3.9 \\
\hline $\begin{array}{l}\text { State unemployment rate, } \\
\text { pre-casino }(\%)\end{array}$ & 8.2 & 8.2 & 7.5 & 7.5 & 3.7 & 4.2 \\
\hline $\begin{array}{l}\text { State unemployment rate, } \\
\text { post-casino }(\%)\end{array}$ & 5.5 & 5.5 & 5.4 & 5.4 & 3.3 & 4.7 \\
\hline $\begin{array}{l}\text { Employment/population ratio, } \\
\text { pre-casino }\end{array}$ & 0.430 & 0.302 & 0.381 & 0.400 & 0.477 & 0.534 \\
\hline $\begin{array}{l}\text { Employment/population ratio, } \\
\text { post-casino }\end{array}$ & 0.507 & 0.591 & 0.509 & 0.418 & 0.449 & 0.531 \\
\hline First casino opened & $2 / 93$ & $8 / 92$ & 2/93 & $7 / 93$ & $11 / 94$ & $3 / 97$ \\
\hline
\end{tabular}

NOTE: All employment data are from December 2001, and population data are from 1999. Home-county casino employment was obtained from contacting casinos. For multiple casinos in a county, the above figure represents the county average.

interindustry substitution between casino gaming and certain local businesses.

\section{Local Employment-Empirical Analysis}

Several academic studies have explored the impact of casinos on local employment. While their conclusions are somewhat mixed, the studies generally suggest that casinos do increase employment in the local area (or at least they do not lead to an employment decrease). Grinols (1994) studied Illinois casinos and found that, of the eight casinos in the state, six have had no significant impact on total employment since their introduction. Using a different methodology, Hewings, Schindler, and Nafziger (1996) found that Illinois casinos generated over 17,000 new jobs. In a study of Colorado casinos, the Center for Business and Economic Forecasting (1995) found that Native American gaming led to 6,100 new jobs. Leven and Phares (1997) found that nearly 12,200 new jobs were created as a result of Missouri casinos.

This section presents two analyses of county employment changes after the introduction of casinos. The first analysis uses monthly household employment data to explore the effect of casinos on resident employment in each county; the second analysis uses annual payroll employment data to detect employment changes in specific industries. It is important to consider that household and payroll employment data measure employment in different ways, so the figures for each will be neither equal nor directly comparable. Household employment is derived from a survey of households and is the number of people in the county who are employed, regardless of where they are employed; county pay- 
roll employment is derived from a survey of firms and is the number of jobs in the county.

The counties used in the analyses are Warren County (Vicksburg casino market) and Tunica County (Tunica casino market) in Mississippi; Massac County (one casino) and St. Clair County (one casino) in Illinois; Lee County (one casino) in Iowa; and St. Louis County (one casino) in Missouri. Of these six counties, St. Louis and St. Clair counties are classified as urban counties and the rest as rural. Detailed employment statistics for each of the six counties are shown in Table 3.

For the first analysis, total household employment is compared before and after casino introduction. For each county, an empirical model is developed to capture employment changes several years before casino introduction. These changes are then used to forecast employment changes from the date of casino introduction through December 2001 (the end of the sample period). These forecasts represent the level of employment that would have existed if the casinos had not been opened. The difference between the actual and forecasted employment is the estimated effect of the casinos.

The second analysis uses payroll employment data to compare county employment in construction, manufacturing, retail trade, services, and finance before and after casino introduction. ${ }^{13}$ If casinos cause an influx of new businesses and/or residents to the county, employment in these sectors may have increased since the introduction of casino gaming. Based on previous studies, this may be especially true for services and retail trade employment. Conversely, if casinos cannibalize existing retail and services sector businesses, then employment in these sectors may have decreased since casino gaming was introduced.

Data and Methodology for Household Employment Forecasts. Seasonally adjusted monthly household employment was obtained from the U.S. Bureau of Labor Statistics for each of the six counties over the period 1986:01-2001:12. Since the six counties introduced casino gaming in the early to mid-1990s, the length of the data series was chosen to ensure an adequate sample of observations pre- and post-casino adoption.

The behavior of the employment series for each county prior to casino adoption (see bottom of

\footnotetext{
13 The analysis does not consider employment in agriculture, government, or transportation because employment in these sectors is unlikely to be significantly affected by casino gaming. A description of the businesses included in each of the five sectors can be found at www.census.gov/epcd/cbp/map/97data/29/189.txt.
}

Table 3 for casino opening dates) is captured using an $\operatorname{ARIMA}(p, d, q)$ model, which is defined as

$$
\begin{aligned}
x(t) & =\gamma+\alpha_{1} x(t-1)+\ldots+\alpha_{p} x(t-p) \\
& +e(t)+\beta_{1} e(t-1)+\ldots+\beta_{q} e(t-q),
\end{aligned}
$$

where $x$ is county household employment, $\gamma$ is a constant term, $e(t)$ is the error term, $p$ is the number of autoregressive lags, and $q$ is the number of movingaverage lags. Augmented Dickey-Fuller (ADF) tests for stationarity were conducted on the employment series (pre-casino adoption) for each of the six counties to determine the order of integration $(d) .{ }^{14}$ The ADF tests reveal that employment for St. Clair County and St. Louis County is stationary in levels, employment for Lee County is trend stationary (a linear time trend is included in the above equation), and employment for Tunica, Massac, and Warren counties is first-difference stationary (where $x(t)$ becomes $\Delta x(t)=x(t)-x(t-1))$.

The Akaike information criterion was used to determine the model order for each county's employment series. The appropriate ARIMA models are as follows: Tunica County ARIMA(2,1,1), Massac County $\operatorname{ARIMA}(1,1,0)$, Warren County $\operatorname{ARIMA}(2,1,0)$, St. Clair County ARIMA $(1,0,4)$, Lee County ARIMA $(1,0,0)$, and St. Louis County $\operatorname{ARIMA}(1,0,2) \cdot{ }^{15}$

Visual inspection of the St. Louis County and St. Clair County employment series reveals marked business cycle effects. No discernable effects are present for the four rural counties. To capture these effects in the empirical models, the coincident index for both Missouri and Illinois is included as a variable in their respective ARIMA model. Based on model order tests, contemporaneous values of the Illinois coincident index are included in the St. Clair County model and contemporaneous and one-lag values of the Missouri coincident index are included in the St. Louis County model. ${ }^{16}$

\footnotetext{
${ }^{14}$ The ADF test results are available from the author.

${ }^{15}$ Following Perron (1989), the ARIMA models also account for, if necessary, structural changes in the employment series prior to casino introduction by including binary dummy variables. Visual inspection of the data reveals structural breaks in the Massac County and St. Louis County data. Thus, the equation for Massac County includes a binary dummy variable that has a value of 1 for 1990:01 and the St. Louis County equation includes a binary dummy variable that has a value of 1 over the period 1990:01-1993:01

16 The coincident index for each state weights changes in payroll employment, average hours worked in manufacturing, the unemployment rate, and real wages paid. Monthly state-level coincident indices are available from the Federal Reserve Bank of Philadelphia at www.phil.frb.org/econ/stateindexes/index.html. See Crone (2002) for a discussion of regional coincident indices.
} 


\section{Figure 1}

\section{Warren County, MS-Household Employment}

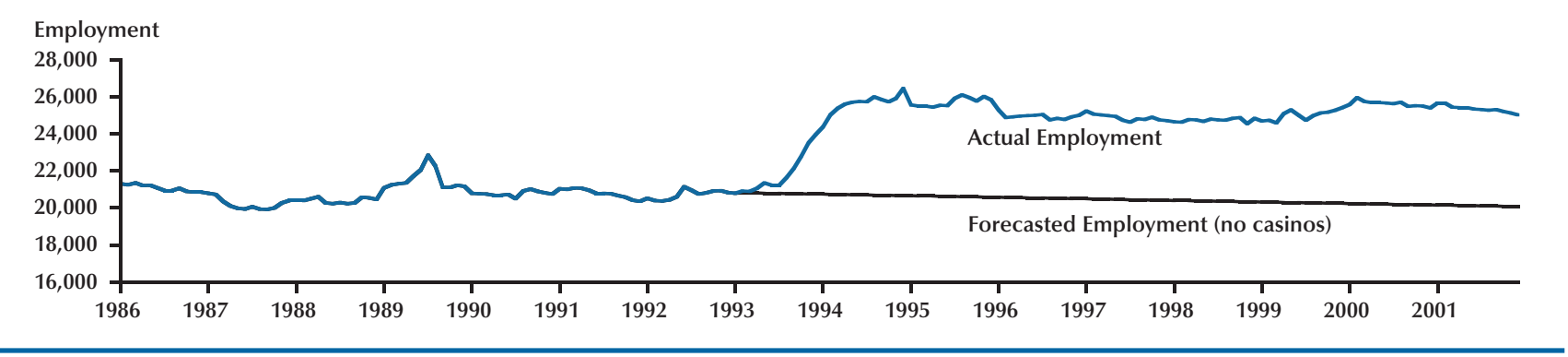

\section{Figure 2}

\section{Tunica County, MS-Household Employment}

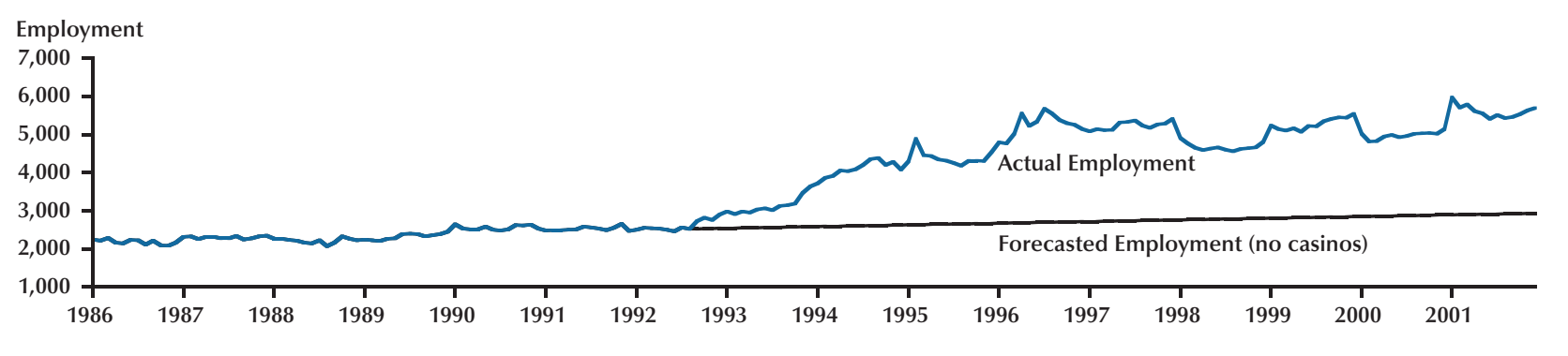

Using the coefficient estimates from the ARIMA models, employment is forecasted dynamically from the month of casino adoption through 2001:12 and is compared with actual employment since the beginning of casino operation. ${ }^{17}$

Results for Household Employment Forecasts

Warren and Tunica Counties, Mississippi. Actual and forecasted household employment for Warren and Tunica counties in Mississippi are shown in Figures 1 and 2. Both are rural counties, and casino gaming constitutes a major industry in each county. The figures reveal that employment in both counties significantly increased since the adoption of casino gaming. There was a dramatic jump in employment in Warren County in 1993 and 1994, the two years in which casinos began operations. Since that time, employment growth has been relatively flat. Employment in Tunica County has grown steadily since the first casino was introduced in late 1992, reflecting the steady increase in the number of casinos in Tunica County throughout the middle and late 1990s. Forecasted employment for the 1990s reveals that,

\footnotetext{
${ }^{17}$ Estimates from the ARIMA models are available from the author.
}

without casino gaming, employment would have decreased slightly in Warren County (about 7 jobs per month), but would have increased slightly in Tunica County (about 3 jobs per month).

As of December 2001, Tunica County household employment increased by 3,144 since the introduction of the first casino, while the population increased by 1,172 . Warren County employment increased by 4,225 since the introduction of the first casino, while its population increased by 910 . Therefore, much of the increase in household employment occurred for pre-casino residents rather than new residents. The employment-to-population ratios for both counties have also increased since the introduction of casino gaming (see Table 3). The employmentto-population ratio increased by nearly 27 percentage points in Tunica County and by over 7 percentage points in Warren County. Casino employment in Tunica County is greater than the population of the county, so the bulk of employees who work in Tunica casinos live outside of the county. In Warren County, total casino employment for residents is about 1,800 , but the increase in employment since casino introduction was nearly 5,000 with little change (910) in population. This suggests that over the 


\section{Figure 3}

\section{St. Clair County, IL-Household Employment}

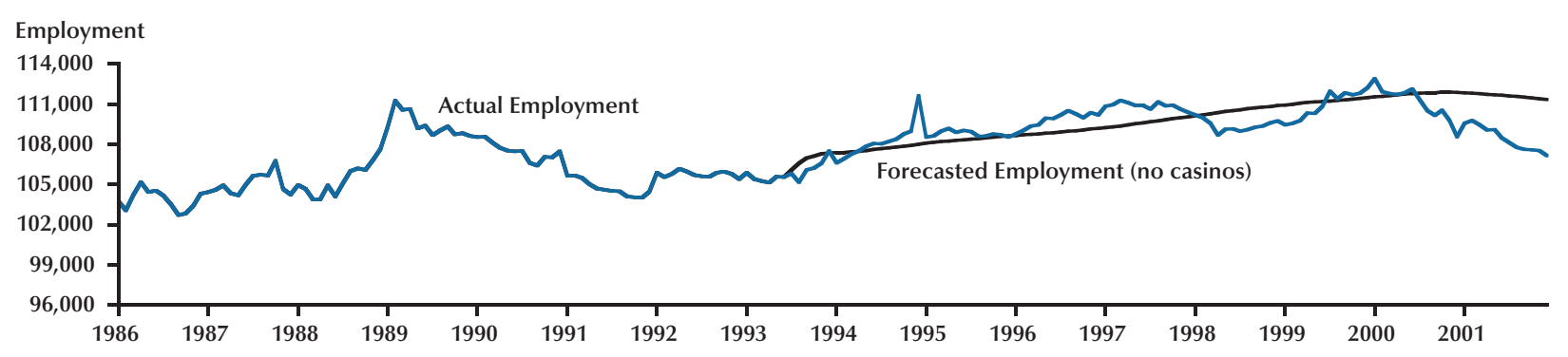

\section{Figure 4}

\section{Massac County, IL-Household Employment}

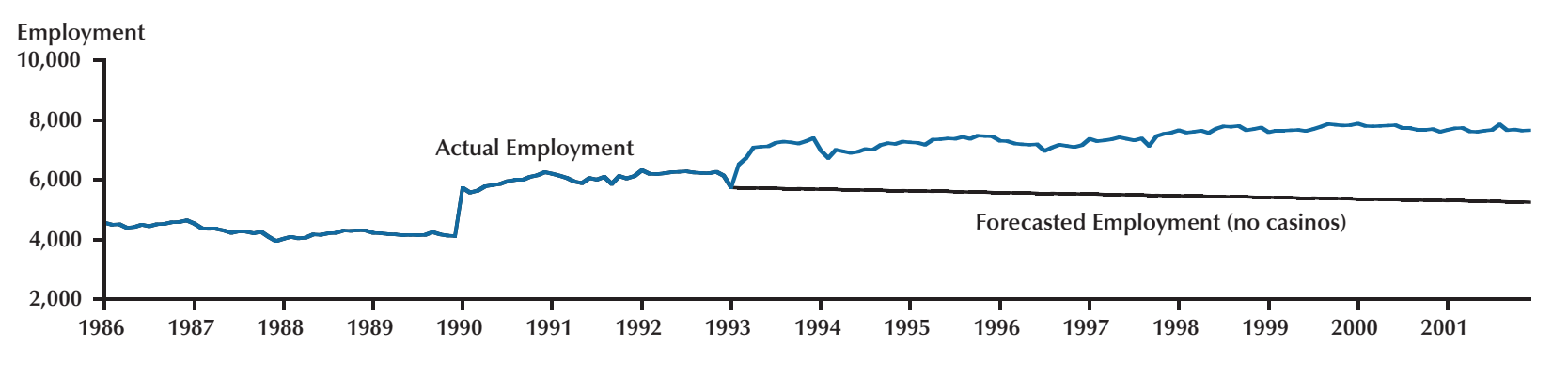

sample period there was employment growth in Warren County outside of the casino industry.

St. Clair and Massac Counties, Illinois. Figures 3 and 4 show actual and forecasted employment for urban St. Clair County and rural Massac County in Illinois. St. Clair County employment is relatively more volatile. In a county with over 250,000 people and household employment near 108,000, the exact impact of one casino on local employment is hard to determine given the relative smallness of casino employment to total employment and the volatility of overall county employment. Prior to 2000, actual and forecasted employment trended upward. Beyond this point, however, actual employment fell below the forecasted decrease in employment. Total employment has risen 1,601 since the introduction of the casino (the casino employs 1,184 people, 947 of whom are from St. Clair County), but the population of St. Clair County has decreased nearly 7,500. As a result, the employment-to-population ratio has increased slightly from the pre-casino period (1.7 percentage points). It thus appears that casino gaming has not hurt St. Clair County employment, but the volatility of total employment and the loss in population leads one to question the overall ability of one casino to maintain or foster employment growth in an urban area.

Employment in rural Massac County markedly increased when the casino began operations and has increased steadily since then. Without the introduction of casino gaming, employment forecasts show a decrease at a rate of about 5 jobs per month. By the end of 2001, actual employment was higher than forecasted employment, but the growth in actual employment has been relatively slow since the introduction of casino gaming. Employment increased by 1,927 since the introduction of casino gaming, which employs 389 persons from Massac County, and the population of Massac County increased by 18. As in Warren and Tunica counties, the vast majority of employment growth in Massac County occurred for pre-casino residents rather than new arrivals. In addition, the bulk of employment growth occurred outside of the casino industry. The employment-to-population ratio for Massac County increased nearly 13 percentage points since the introduction of casino gaming.

Lee County, Iowa. Forecasted and actual employ- 


\section{Figure 5}

\section{Lee County, IA-Household Employment}

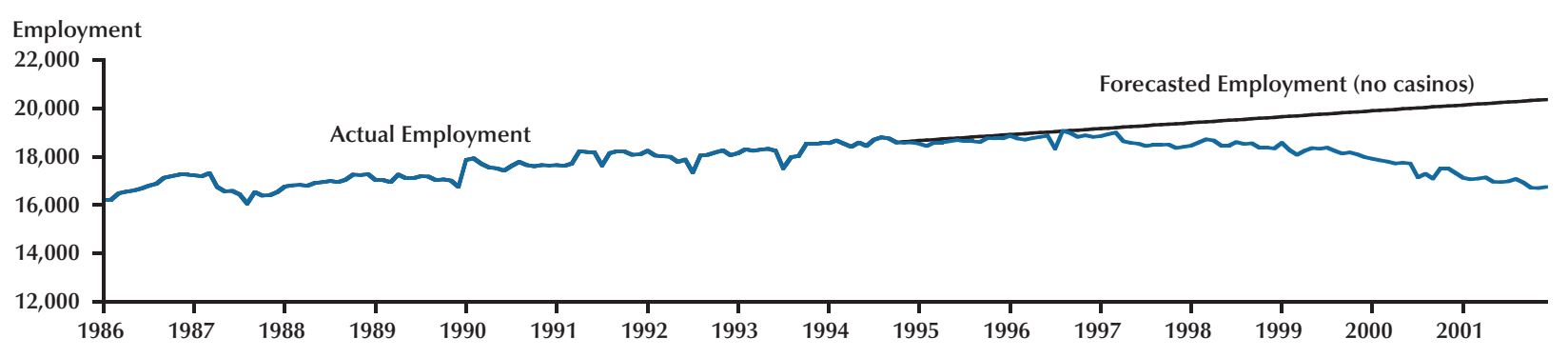

\section{Figure 6}

\section{St. Louis County, MO-Household Employment}

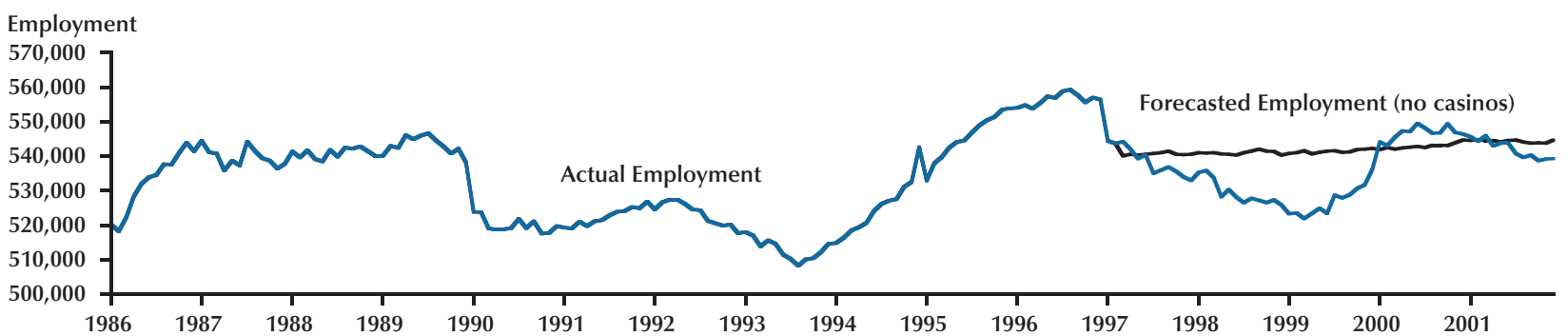

ment for rural Lee County, Iowa, are shown in Figure 5. Actual employment remained relatively constant around the time the casino began operations but has steadily decreased since then. Forecasted employment continued a gradual increase (about 20 jobs per month) since the date of casino introduction. At the end of 2001, Lee County had lost 1,846 jobs since the casino began operations and experienced a population decrease of 1,652 . As a result, the employment-to-population ratio decreased by nearly 3 percentage points since the casino was introduced. Unlike rural counties such as Massac County in Illinois and Tunica and Warren counties in Mississippi, the introduction of casino gaming in Lee County has not corresponded to an increase in employment. It is possible, however, that the introduction of casino gaming has slowed the decrease in employment and population in Lee County.

St. Louis County, Missouri. St. Louis County's total household employment is nearly 550,000. As in urban St. Clair County, household employment in St. Louis County is quite variable over the sample period (Figure 6). The impact of one casino employ- ing 2,050 people, only 32 percent of whom are from St. Louis County, cannot be accurately inferred from the data. Employment continued to fall after the casino was introduced but then slightly increased above forecasted levels in 2000. It is possible that the casino has created some jobs, but the direct impact of the casino on total employment is masked by highly variable total employment and the relatively small employment contribution made by a single casino.

Payroll Employment Changes by Sector. Because the payroll employment data are listed on an annual basis, this study's small sample size is not adequate for running forecast models. Thus, the analysis involves comparing employment levels in each sector before and after the introduction of casinos. Sector employment changes in these two periods for each of the six counties are shown in Tables 4 through 9. For each county, services sector employment excludes casino employment, which is listed as a separate sector. Recall that changes in sector employment cannot be directly compared with household employment changes in the previous section because the two employment measures are different. 


\section{Table 4}

Warren County, MS, Payroll Employment Changes by Sector

\begin{tabular}{lccc} 
& \multicolumn{3}{c}{ Employment } \\
\cline { 2 - 4 } Sector & 1993 & $\mathbf{2 0 0 1}$ & Gain or loss (\% change) \\
\hline Manufacturing & 3,408 & 5,090 & $1,682(49.4)$ \\
Retail trade & 3,926 & 2,932 & $-994(-25.3)$ \\
Services & 4,114 & 7,674 & $3,560(86.5)$ \\
Financial & 597 & 487 & $-110(-18.4)$ \\
Construction & 363 & 590 & $227(62.5)$ \\
Casinos & - & 2,443 & 2,443
\end{tabular}

Total gain or loss

$6,808(54.9)$

NOTE: The first casino opened in February 1993. Services sector employment excludes casino employment.

SOURCE: Data are from the U.S. Census Bureau. 1993: www.census.gov/epcd/cbp/map/93data/28/149.txt.

2001: www.census.gov/epcd/cbp/map/01data/28/149.txt.

\section{Table 5}

Tunica County, MS, Payroll Employment Changes by Sector

\begin{tabular}{lccc} 
& \multicolumn{3}{c}{ Employment } \\
\cline { 2 - 4 } Sector & 1992 & $\mathbf{2 0 0 1}$ & Gain or loss (\% change) \\
\hline Manufacturing & 375 & 614 & $239(63.7)$ \\
Retail trade & 204 & 374 & $170(83.3)$ \\
Services & 123 & 2,441 & $2,318(1884.5)$ \\
Financial & 77 & 99 & $22(28.6)$ \\
Construction & 15 & 60 & $45(300.0)$ \\
Casinos & - & 12,689 & 12,689
\end{tabular}

Total gain or loss

$15,483(1950.0)$

NOTE: The first casino opened in August 1992. Services sector employment excludes casino employment.

SOURCE: 1992 data are from GovStats: http://govinfo.kerr.orst.edu/php/commerce/state/show.php. 2001 data are from the U.S. Census Bureau: www.census.gov/epcd/cbp/map/01data/28/143.txt.

Warren County, Mississippi (Table 4), experienced a large increase in manufacturing, services, and construction employment since the introduction of casino gaming, which constitutes 36 percent of the total increase in payroll employment. The increase in manufacturing employment is quite large, given the national decrease in manufacturing employment during the 1990s. Moderate decreases in retail trade and financial employment occurred within the county over the same time period.
Because casino gaming is a relatively large industry in Warren County, the findings suggest that the increase in services sector employment and decrease in retail trade employment may be attributed to casino gaming.

Tunica County, Mississippi (Table 5), had employment increases in all five sectors, with the largest increase in the services sector. Given that casino gaming is the predominant industry in Tunica County, the data in Table 5 suggest that employment 


\section{Table 6}

\section{St. Clair County, IL, Payroll Employment Changes by Sector}

\begin{tabular}{lccc} 
& \multicolumn{3}{c}{ Employment } \\
\cline { 2 - 4 } Sector & 1993 & $\mathbf{2 0 0 1}$ & Gain or loss $(\%$ change $)$ \\
\hline Manufacturing & 7,318 & 6,724 & $-594(-8.1)$ \\
Retail trade & 18,154 & 12,872 & $-5,282(-29.1)$ \\
Services & 25,922 & 39,102 & $13,180(50.8)$ \\
Financial & 3,158 & 4,274 & $1,116(35.3)$ \\
Construction & 2,626 & 3,927 & $1,301(49.5)$ \\
Casino & - & 1,184 & 1,184
\end{tabular}

Total gain or loss

$10,905(19.1)$

NOTE: The casino opened in July 1993. Services sector employment excludes casino employment.

SOURCE: Data are from the U.S. Census Bureau. 1993: www. census.gov/epcd/cbp/map/93data/17/163.txt. 2001: www.census.gov/epcd/cbp/map/01data/17/163.txt.

\section{Table 7}

Massac County, IL, Payroll Employment Changes by Sector

\begin{tabular}{lccc} 
& & Employment & Gain or loss (\% change) \\
\cline { 2 - 4 } Sector & 1993 & $\mathbf{2 0 0 1}$ & $-98(-13.3)$ \\
\hline Manufacturing & 736 & 638 & $-342(-49.2)$ \\
Retail trade & 695 & 353 & $505(57.8)$ \\
Services & 874 & 1,379 & $90(83.3)$ \\
Financial & 108 & 198 & $-26(-20.6)$ \\
Construction & 126 & 100 & 883
\end{tabular}

Total gain or loss

$1,012(39.9)$

NOTE: The casino opened in February 1993. Services sector employment excludes casino employment.

SOURCE: Data are from the U.S. Census Bureau. 1993: www. census.gov/epcd/cbp/map/93data/17/127.txt.

2001: www.census.gov/epcd/cbp/map/01data/17/127.txt.

increases in the various sectors can be attributed, in large part, to the introduction of casino gaming. Overall payroll employment increased by over 1,900 percent since casino gaming was introduced in 1992; a large portion of this increase (82 percent) is attributed to casino employment.

Casino gaming in St. Clair County, Illinois (Table 6), contributed to roughly 11 percent of the gain in payroll employment since casino gaming was introduced. Services, finance, and construction employment all increased by an average of 43 percent, but manufacturing and retail trade decreased by 8 percent and 29 percent, respectively. The employment impact of casino gaming has been much smaller than changes in other sectors, but it still has contributed moderately to net changes in total payroll employment.

Massac County, Illinois (Table 7), experienced 


\section{Table 8}

Lee County, IA, Payroll Employment Changes by Sector

\begin{tabular}{|c|c|c|c|}
\hline \multirow[b]{2}{*}{ Sector } & \multicolumn{3}{|c|}{ Employment } \\
\hline & 1994 & 2001 & Gain or loss (\% change) \\
\hline Manufacturing & 5,991 & 5,130 & $-861(-14.4)$ \\
\hline Retail trade & 3,144 & 2,057 & $-1,087(-34.6)$ \\
\hline Services & 3,573 & 5,229 & $1,656(46.3)$ \\
\hline Financial & 482 & 558 & $76(15.8)$ \\
\hline Construction & 796 & 669 & $-127(-16.0)$ \\
\hline Casino & - & 367 & 367 \\
\hline
\end{tabular}

Total gain or loss

$24(0.17)$

NOTE: The casino opened in November 1994. Services sector employment excludes casino employment.

SOURCE: 1994 data are from GovStats: http://govinfo.kerr.orst.edu/php/commerce/state/show.php. 2001 data are from the U.S.

Census Bureau: www.census.gov/epcd/cbp/map/01data/19/111.txt.

\section{Table 9}

St. Louis County, MO, Payroll Employment Changes by Sector

\begin{tabular}{lccc} 
& \multicolumn{3}{c}{ Employment } \\
\cline { 2 - 4 } Sector & 1997 & $\mathbf{2 0 0 1}$ & Gain or loss (\% change) \\
\hline Manufacturing & 97,608 & 59,048 & $-38,560(-39.5)$ \\
Retail trade & 113,407 & 74,170 & $-39,237(-34.6)$ \\
Services & 207,947 & 287,982 & $80,035(38.5)$ \\
Financial & 45,162 & 49,869 & $4,707(10.4)$ \\
Construction & 32,087 & 39,876 & $7,789(24.3)$ \\
Casino & - & 2,050 & 2,050
\end{tabular}

Total gain or loss

$16,784(3.38)$

NOTE: The casino opened in March 1997. Services sector employment excludes casino employment.

SOURCE: Data are from the U.S. Census Bureau. 1997: www. census.gov/epcd/cbp/map/97data/29/189.txt.

2001: www.census.gov/epcd/cbp/map/01data/29/189.txt.

an increase in services and financial employment but a decrease in other sectors. With the introduction of casino gaming, payroll employment increased nearly 40 percent. Casino gaming has provided the largest contribution to the increase in total payroll employment in Massac County (87 percent). Without it, the gain in total payroll employment in Massac County would have been roughly 130 persons.

Without casino gaming, Lee County, Iowa
(Table 8), would have experienced an overall decrease in payroll employment since casino introduction. While services and financial employment increased over the sample period, these increases were met by larger decreases in manufacturing, retail trade, and construction employment, resulting in the loss of 343 jobs. Casino employment of 367 persons provided a net gain of 24 jobs in Lee County. Household employment and population fell for Lee County, 
but payroll employment remained relatively constant since casino introduction. This suggests that either some of the original population in Lee County moved outside of the county and continues to work in Lee County or more residents of neighboring counties now work in Lee County.

Like St. Clair County in Illinois, the casino industry is a relatively minor employer in St. Louis County, Missouri (Table 9). However, the 2,050 casino jobs contributed to roughly 12 percent of the increase in total payroll employment in St. Louis County (similar to the 11 percent in urban St. Clair County). Large decreases in manufacturing and retail trade occurred, but these decreases were met with slightly larger increases in services, financial, and construction employment. Thus, even though casino gaming may be a minor industry in urban areas, casino gaming can make up a moderate portion of net payroll employment gains or losses.

\section{SUMMARY AND CONCLUSIONS}

The employment effects of casino gaming are difficult to quantify. A casino may draw labor from outside of the local area, thus leaving local employment conditions unchanged if that labor does not relocate to the local area. Casinos are only synonymous with economic development if they create a greater value to society. It is possible that casino gaming may reduce employment in other local industries if consumers substitute casino gaming for other consumption. The net effect of gaming could be positive or negative depending upon the degree to which casino gaming substitutes for or complements consumption at other local businesses.

Determining the possible impact of casino gaming on local employment involves an examination of employment changes in the local area before and after the introduction of casino gaming. The empirical analysis presented here reveals that, in three of four cases, rural counties that adopted casino gaming experienced increases in household and payroll employment. This seems to hold even though casino employment is dispersed over several counties rather than just the home county. Also, employment gains are much greater in rural counties that have adopted casino gaming as a major or predominant industry. It is harder to detect the impact of casino gaming in more-metropolitan counties, where employment is highly variable and casino gaming constitutes a small portion of total employment. However, casino gaming in urban areas can still constitute a moderate portion of net payroll employ- ment gains or losses even though casino gaming is a minor industry; still, the impact is much greater in rural counties with casino gaming.

One question that remains is, How much will the gaming industry grow in the future? The current budget crises facing state and local governments may generate further expansion of casino gaming across the country. There is little evidence that the industry has reached the saturation point-a "build it and they will come" attitude pervades the industry at the current time. While the evidence here suggests that rural counties that adopt casino gaming as a major industry are likely to see large employment gains, this does not suggest that every county can become like Tunica, Mississippi. Attitudes regarding the spread of casino gaming in a given local area, costly industry regulation, and increasing casino competition may hinder the growth of gaming in rural areas.

The degree to which state and local governments currently rely on casino revenue raises the question of whether or not the casino industry is recessionproof. One may expect that the growth of the casino industry is contingent upon economic conditions; if the industry is highly procyclical, then casino revenues may do little to lessen the budgetary impacts of an economic slowdown. This may be true: In fact, many states with casinos are facing budget crises similar to those of states without casinos. However, little research has been done on this issue. Regardless of what the future holds, there is little doubt that casinos are here to stay and that more communities will be faced with the question of whether to adopt casino gaming.

\section{REFERENCES}

Ader, Jason N. Bear Stearns 2002-2003 North American Gaming Almanac. Las Vegas: Huntington Press, 2003.

Anders, Gary; Siegel, Donald and Yacoub, Munther. "Does Indian Casino Gambling Reduce State Revenues? Evidence from Arizona." Contemporary Economic Policy, July 1998, 16(3), pp. 347-55.

Blois, T.; Cunningham, S. and Lott, W. "The Bridgeport Casino Proposals: An Economic Evaluation.” Prepared for the Connecticut Department of Economic and Community Development and the Connecticut Department of Special Revenue. Storrs, CT: Connecticut Center for Economic Analysis, October 1995. 
Center for Business and Economic Forecasting, Inc. Economic Impact of Limited Gaming in Colorado. Report prepared for the Colorado Casino Owners Association, Regis University, January 1995.

Crone, Theodore. "Consistent Economic Indexes for the 50 States.” Working Paper No. 02-7/R, Federal Reserve Bank of Philadelphia, May 2002.

Gazel, R.; Thompson, W. and Rickman, D. "The Economic Impact of Native American Gaming in Wisconsin." Gaming Research and Review Journal, 1995, 2(2), pp. 43-62.

GovStats. http://govinfo.kerr.orst.edu/php/commerce/state/ show.php.

Grinols, Earl. "Bluff or Winning Hand? Riverboat Gambling and Regional Employment and Unemployment." Illinois Business Review, Spring 1994, 51(1), pp. 8-11.

Grinols, Earl. "Cutting the Cards and Craps: Right Thinking About Gambling Economics" in G. Reith, ed., Gambling: Debating the Issues, Prometheus Contemporary Issues Series. New York: Prometheus (forthcoming).

Hewings, G.; Schindler, G. and Nafziger, B. "The Impact of Riverboat Casino Gambling on the Illinois Economy 1991 1995." Report to the Illinois Gaming Board. Chicago: Regional Economics Applications Laboratory, 1996.

KPMG Management Consulting. One Year Review of Casino Windsor. Report prepared for Ontario Casino Corporation, Toronto, 1995.
Leven, Charles and Phares, Donald. "Casino Gaming in Missouri: The Spending Displacement Effect and Net Economic Impact." Proceedings of the 90th Annual Conference on Taxation, National Tax Association, Chicago, November 1997, pp. 431-38.

National Conference of State Legislatures. State Budget Update. Washington, DC: National Conference of State Legislatures, February 2003.

National Gambling Impact Study Commission. Final Report. Washington, DC: National Gambling Impact Study Commission, 1999.

Perron, Pierre. "The Great Crash, the Oil Price Shock, and the Unit Root Hypothesis." Econometrica, November 1989, 57(6), pp. 1361-401.

Przybylski, Michael; Felsenstein, Daniel; Freeman, Daniel and Littlepage, Laura. "Does Gambling Complement the Tourist Industry? Some Empirical Evidence of Import Substitution and Demand Displacement." Tourism Economics, September 1998, 4(3), pp. 213-31.

Siegel, Donald and Anders, Gary. "Public Policy and the Displacement Effects of Casinos: A Case Study of Riverboat Gambling in Missouri." Journal of Gambling Studies, Summer 1999, 15(2), pp. 105-21.

U.S. Census Bureau. www.census.gov. 